\title{
Promotion of RES in a Technology Transfer Network. Case Study of the Enterprise Europe Network
}

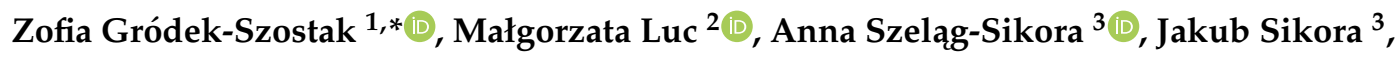 \\ Marcin Niemiec ${ }^{4}$, Luis Ochoa Siguencia ${ }^{5}$ (D) and Emil Velinov 6,7 (D) \\ 1 Department of Economics and Enterprise Organization, Cracow University of Economics, \\ 31-510 Krakow, Poland \\ 2 Department of Geographical Information Systems, Cartography and Remote Sensing, Jagiellonian \\ University in Cracow, 30-387 Kraków, Poland; malgorzata.luc@uj.edu.pl \\ 3 Faculty of Production and Power Engineering, University of Agriculture in Krakow, 30-149 Kraków, Poland; \\ Anna.Szelag-Sikora@ur.krakow.pl (A.S.-S.); Jakub.Sikora@ur.krakow.pl (J.S.) \\ 4 Faculty of Agriculture and Economics, University of Agriculture in Krakow, 31-121 Kraków, Poland; \\ Marcin.Niemiec@ur.krakow.pl \\ 5 Academy of Physical Education in Katowice, 40-065 Katowice, Poland; l.ochoa@awf.katowice.pl \\ 6 Department of Management and Marketing, Skoda Auto University, 1457 Na Karmeli, Czech Republic; \\ emil.velinov@savs.cz \\ 7 Department of Business Studies, RISEBA University of Applied Science, LV-1048 Riga, Latvia \\ * Correspondence: grodekz@uek.krakow.pl
}

Received: 29 May 2020; Accepted: 1 July 2020; Published: 3 July 2020

check for updates

\begin{abstract}
The promotion of renewable energy is a key concept in the European Union for both environmental and economic reasons. It contributes to securing the objectives set out in the Kyoto Protocol. In addition, it brings various social and economic benefits, e.g., diversification of the energy offer, new jobs, improvement of regional and local development opportunities and building a solid national industry. The main purpose of the article is to contribute to the debate on the instruments promoting renewable energy sources (RES) by emphasizing its importance within the technology transfer network. The subject is an empirical study of an actual technology transfer network. Its international activity promotes RES among entrepreneurs. Data related to meetings as part of brokerage events (BE) and company missions (CM) were subject to statistical and visual analysis, based on the data obtained from the Enterprise Europe Network from the years 2017-2018. The presented results are the foundation for future theoretical and practical studies. One of the important aspects to be examined is the intensity of cooperation launched during CM and BE. It is related to the results of partnership agreements and the importance of increasing the knowledge flow and creating opportunities for partners to acquire foreign technologies.
\end{abstract}

Keywords: RES; company mission; brokerage events; cooperation; network

\section{Introduction}

In a situation where the advancement of new sustainable technologies is key to tackling the challenges related to the climate and environment in the 21st century, these technologies face significant development and implementation obstacles. One of the reasons is that technologies are usually associated with dominant business models, value chains, industry standards and certain institutions [1]. Therefore, the transition to more sustainable production methods often requires relatively long development periods. This is because technology-specific business networks, value chains, institutions, etc., must be introduced and adapted to the emerging technologies. This means that a sustained technological change can potentially be affected by a number of market, systemic and institutional 
shortcomings [2]. This, in turn, requires adopting an innovation policy based on a blend of multi-faceted political interventions [3-5]. For example, it has long been known that to stimulate innovation, it is necessary to combine technology-driving and promotion instruments that attract demand.

Energy relates to both the political and economic elements of international business relations. Therefore, it is one of the basic instruments for launching, maintaining and strengthening the existing regional partnership programs [6]. The lack of information on mutual credibility and preferences significantly hampers cooperation $[7,8]$. In this perspective, seeking formal, semi-formal or informal cooperation with regional institutions of the partner countries is a practical way to reach improved energy integration. In order for the economy to develop, including the RES market, it needs an institutional environment that will enable and support market activities. Shirley [9] divides the institutions into two sets, not necessarily complementary. The first group includes the elements of support that facilitate market exchange by reducing transaction costs and increasing confidence. The second group were the elements that strengthen private ownership and individual freedom, rather than use and subordinate them to the centralized state power. In order for the process of economic development to be sustainable, political institutions must be transformed along with the socio-economic climate. Hence, the institutional support system for market processes plays an important role by inducing development and promotion of RES in the economy. Sanderink and Nasiritousi [10] have shown that institutional interactions can increase the effectiveness of institutional partnerships for renewable energy.

Progress trends in highly developed countries demonstrate that building [11] a competitive edge based on R\&D research results and the exploitation of scientific and technical progress can guarantee long-term, sustainable development [12-14]. The high level of innovation in energy and environmental technologies improves the competitiveness of economies and minimizes the negative impact of man's activities on the environment, also by reducing emissions of greenhouse gases [15-18]. Therefore, achieving the sustainable development goals, i.e., a low-carbon and environmentally friendly economy, requires support of activities that popularize and promote energy technologies.

When the Directive 2018/2001 on the promotion of the use of energy from renewable sources ("RED II Directive") entered into force, a new, prospective framework was established. Its purpose was to achieve the set target of at least $32 \%$ of RES energy in EU's total gross energy consumption by 2030. These new frameworks are based, e.g., on the commitment of Member States to use the 2020 targets as the foundation for their targets for the next decade. Other parts of the Clean Energy for All Europeans package complement the framework [19]. The European Union is also a leader in applying various renewable energy technologies in their supply chains. For some technologies, e.g., wind turbines, the EU producers represented at least $41 \%$ of the 2016 annual global installed capacity [20]. EU producers are also global leaders in the EU photovoltaic (PV) sector, with a 50\% share of the market. The share of EU inverter producers in the global market exceeds $18 \%$ [21]. Through the financial mechanisms of the HORIZON 2020 program, the EU finances a number of projects aimed at developing and popularizing innovative RES solutions. For instance, FracRisk was an EU-funded project aiming at improving the understanding of potential environmental impacts of shale gas exploration by hydraulic fracturing $[22,23]$.

The establishment of international climate policy facilitate decentralized energy production and constant growth of RES technology markets [24,25]. This market growth is supported, e.g., by international and EU policies on renewable energy production, EU directives on the growing competition in the electric power industry and the growing prices of fossil fuels. Local energy production increases energy efficiency due to lower transportation or transfer losses, as well as supports local business [26]. Production of energy from local waste reduces waste management costs, thus enabling other local businesses to emerge and offer new jobs. By reducing dependence on imports, local energy production also increases power and fuel security [27].

The promotion of renewable energy is a pivotal concept in the European Union both in terms of the environment, and economy. It supports securing the objectives set out in the Kyoto Protocol 
and brings various social and economic benefits. These are, e.g., diversification of the energy offer, new jobs, improvement of regional and local development opportunities and building a solid national industry [28]. The carbon capture and storage (CCS) technology transfer model was described by Liu and Liang [29]. The authors built a four-stage model including physical transfer of non-confidential technologies, the financial mechanism, as well as building endogenous capacity and the mechanism of monitoring. Seres et al. [30] took up the topic of technology transfer in Clean Development Mechanism $(\mathrm{CDM})$ projects, demonstrating that technology transfer is more common in larger projects and in projects including exchange of knowledge and technology with foreign partners. However, any technology transfer requires promotional activities to enhance its effectiveness. In the literature to date, the authors have identified a research gap in RES technology promotion within technology transfer networks, especially financed from public EU funds. The article in question fills the gap by analyzing independent actions, often dispersed, but undertaken for the same purpose, i.e., promoting RES among entrepreneurs.

The main purpose of the article is to contribute to the discussion of the instruments promoting renewable energy sources (RES) by emphasizing their importance within the technology transfer network.

\section{Materials and Methods}

The analysis presented in this paper is carried out by means of an actual technology transfer network. Its international activity promotes RES among entrepreneurs. The subject is the European Enterprise Network (EEN) created in 2008 by the European Commission. It can be seen as an instrument in EU's strategy for economic growth. The EEN is an EU initiative supporting business innovation in Europe's small and medium-sized enterprises (SMEs). The EEN is the largest global network supporting business and innovation. Currently, it comprises 625 partner organizations located in over 60 countries. Over 4000 internationalization experts and technology transfer practitioners offer a wide range of entrepreneurship support and innovation services for enterprises, including business missions (CM) and brokerage meetings (BE) [31,32]. Data related to meetings as part of brokerage events (BE) and company missions (CM) were subject to statistical and visual analysis, based on the data obtained from the Enterprise Europe Network (EEN) from the years 2017-2018.

One of the main anticipated results of the EEN is to increase the connectivity of SMEs to other entities across Europe for international business cooperation, technology and knowledge transfer, as well as innovation partnerships.

As a unique exchange platform for innovative technologies, CMs facilitate establishing direct contacts, initiating and establishing new, industry-specific business partnerships. CMs are the low-cost, direct form of reaching the right potential business partner in their natural environment and allow to get acquainted not only with their offer but also their immediate business and legal environment. In turn, a BM is a quick and direct form of seeking a cooperation partner. It provides an opportunity to exchange information on innovative technologies and new trends, as well as to search for business and technology partners. Prior to the event, BE participants choose their partners for direct B2B meetings, according to the type of cooperation sought [33-35]. Table 1 presents the CE and BE meetings carried out by the EEN between 2017 and 2018. The events were organized according to:

1. Keywords related to the technologies characterizing the event's theme.

2. The event's location (the spatial characteristics), with the country marked, but please note that the fair and exhibition events took place in large urban centers. 
Table 1. List of company missions (CM) and brokerage meetings (BM) topics in respective countries in the years 2017-2018. Source: own study.

\begin{tabular}{|c|c|c|c|}
\hline No. & Country & $\begin{array}{l}\text { Technology Keywords of the } \\
\text { Studied Company Missions }\end{array}$ & $\begin{array}{c}\text { Technology Keywords of the Studied } \\
\text { Brokerage Meetings }\end{array}$ \\
\hline 1. & Austria & $\begin{array}{c}\text { Renewable sources or energy; } \\
\text { solid biomass; biogas and anaerobic } \\
\text { digestion; bio- } \\
\text { refineries for energy }\end{array}$ & $\begin{array}{l}\text { Low, zero and plus energy rating; energy } \\
\text { management }\end{array}$ \\
\hline 2. & Belarus & & Energy management \\
\hline 3. & Belgium & $\begin{array}{l}\text { Energy efficiency; } \\
\text { renewable sources of energy }\end{array}$ & $\begin{array}{l}\text { Energy efficiency; renewable sources of } \\
\text { energy; wind energy; installations related to } \\
\text { construction (energy, lighting); } \\
\text { solar/thermal energy }\end{array}$ \\
\hline 4. & $\begin{array}{l}\text { Bosnia and } \\
\text { Herzegovina }\end{array}$ & & $\begin{array}{l}\text { Renewable sources of energy; geothermal } \\
\text { energy; wind energy; biomass; hydropower; } \\
\text { energy from wastewater; energy } \\
\text { production, transmission and conversion; } \\
\text { photovoltaics; solar/thermal energy }\end{array}$ \\
\hline 5. & Brazil & & Energy management \\
\hline 6. & Bulgaria & $\begin{array}{l}\text { Energy conservation related; } \\
\text { alternative energy }\end{array}$ & \\
\hline 7. & Chile & $\begin{array}{l}\text { Energy production, transmission } \\
\text { and conversion; }\end{array}$ & \\
\hline 8. & China & $\begin{array}{l}\text { Waste to energy-other; biomass and } \\
\text { biofuels; energy efficiency }\end{array}$ & $\begin{array}{l}\text { Renewable sources of energy; alternative } \\
\text { energy }\end{array}$ \\
\hline 9. & Croatia & $\begin{array}{l}\text { Energy production, transmission } \\
\text { and conversion }\end{array}$ & $\begin{array}{l}\text { Energy management; } \\
\text { energy efficiency; } \\
\text { clean production/green technologies; }\end{array}$ \\
\hline 10. & Cyprus & Energy efficiency & \\
\hline 11. & Czech Republic & & Energy efficiency \\
\hline 12. & Denmark & Energy efficiency & $\begin{array}{l}\text { Combined heat and power (CHP) } \\
\text { (Co-generation); } \\
\text { Other alternative energy; CHP engines; } \\
\text { renewable sources of energy; energy supply } \\
\text { system; } \\
\text { energy production, transmission and } \\
\text { conversion }\end{array}$ \\
\hline 13. & Finland & & Photovoltaics; marine energy \\
\hline 14. & France & $\begin{array}{l}\text { Solar/Thermal energy; } \\
\text { renewable sources of energy; }\end{array}$ & $\begin{array}{l}\text { Energy efficiency; wind energy; waste to } \\
\text { energy/resource; waste to energy-other; } \\
\text { geothermal energy; clean production/green } \\
\text { technologies; solid biomass; energy from } \\
\text { wastewater; photovoltaics; integrated } \\
\text { waste-energy processes; }\end{array}$ \\
\hline 15. & Germany & $\begin{array}{l}\text { Solar/Thermal energy; energy } \\
\text { management; renewable sources of } \\
\text { energy; other energy topics; energy } \\
\text { production, transmission and } \\
\text { conversion }\end{array}$ & $\begin{array}{l}\text { Energy management; wind energy; } \\
\text { renewable sources of energy; chemical } \\
\text { technology and engineering; other energy } \\
\text { topics; energy efficiency; }\end{array}$ \\
\hline 16. & Greece & $\begin{array}{l}\text { Energy production, transmission } \\
\text { and conversion }\end{array}$ & \\
\hline 17. & Iceland & & Energy efficiency; geothermal energy \\
\hline 18. & India & Renewable sources of energy & \\
\hline
\end{tabular}


Table 1. Cont.

\begin{tabular}{|c|c|c|c|}
\hline No. & Country & $\begin{array}{l}\text { Technology Keywords of the } \\
\text { Studied Company Missions }\end{array}$ & $\begin{array}{c}\text { Technology Keywords of the Studied } \\
\text { Brokerage Meetings }\end{array}$ \\
\hline 19. & Italy & Renewable sources of energy; & $\begin{array}{l}\text { Renewable sources of energy; energy } \\
\text { production, transmission and conversion; } \\
\text { energy efficiency; }\end{array}$ \\
\hline 20. & Lithuania & $\begin{array}{l}\text { Renewable sources of energy; } \\
\text { solar/thermal energy }\end{array}$ & $\begin{array}{l}\text { Renewable sources of energy; energy } \\
\text { production, transmission and conversion; }\end{array}$ \\
\hline 21. & Luxembourg & & $\begin{array}{l}\text { Renewable sources or energy; energy } \\
\text { production, transmission and conversion; }\end{array}$ \\
\hline 22. & Moldova & & $\begin{array}{l}\text { Renewable sources or energy; energy } \\
\text { production, transmission and conversion; }\end{array}$ \\
\hline 23. & Netherlands & $\begin{array}{l}\text { Solid biomass; bio-refineries for } \\
\text { energy; photovoltaics; waste to } \\
\text { energy }\end{array}$ & $\begin{array}{l}\text { Photovoltaics; solar/thermal energy; wind } \\
\text { energy }\end{array}$ \\
\hline 24. & Norway & $\begin{array}{l}\text { Fuels and engine technologies; } \\
\text { hydropower; energy efficiency; }\end{array}$ & Renewable sources or energy \\
\hline 25. & Poland & $\begin{array}{l}\text { Photovoltaics; renewable sources or } \\
\text { energy; energy efficiency }\end{array}$ & $\begin{array}{l}\text { Renewable sources or energy; energy } \\
\text { production, transmission and conversion }\end{array}$ \\
\hline 26. & Portugal & & $\begin{array}{l}\text { Renewable sources or energy; energy } \\
\text { production, transmission and conversion }\end{array}$ \\
\hline 27. & Romania & $\begin{array}{l}\text { Solid biomass; biogas and anaerobic } \\
\text { digestion; integrated waste-energy } \\
\text { processes; }\end{array}$ & $\begin{array}{l}\text { Renewable sources or energy; geothermal } \\
\text { energy; other energy topics; solar/thermal } \\
\text { energy; }\end{array}$ \\
\hline 28. & Russia & $\begin{array}{l}\text { Renewable sources or energy; other } \\
\text { energy topics; energy efficiency; }\end{array}$ & \\
\hline 29. & Serbia & Renewable sources or energy; & \\
\hline 30. & Slovakia & Renewable sources or energy & Renewable sources or energy \\
\hline 31. & Slovenia & $\begin{array}{l}\text { Energy efficiency; fuels and engine } \\
\text { technologies; geothermal energy; } \\
\text { energy management; wind energy }\end{array}$ & $\begin{array}{l}\text { Energy efficiency; fuels and engine } \\
\text { technologies; geothermal energy; energy } \\
\text { management; wind energy }\end{array}$ \\
\hline 32. & Spain & & $\begin{array}{l}\text { Renewable sources or energy; other energy } \\
\text { topics; energy efficiency }\end{array}$ \\
\hline 33. & Sweden & & $\begin{array}{l}\text { Renewable sources or energy; biogas and } \\
\text { anaerobic digestion (AD); energy } \\
\text { production, transmission and conversion; } \\
\text { energy efficiency }\end{array}$ \\
\hline 34. & Switzerland & & Renewable sources or energy \\
\hline 35. & Taiwan & Photovoltaics & \\
\hline 36. & Turkey & Renewable sources or energy & $\begin{array}{l}\text { Fossil Energy Sources; renewable sources or } \\
\text { energy; other energy topics; biogas and } \\
\text { anaerobic digestion (AD); energy } \\
\text { production, transmission and conversion; } \\
\text { energy efficiency }\end{array}$ \\
\hline 37. & Ukraine & & Renewable sources or energy \\
\hline 38. & $\begin{array}{l}\text { United } \\
\text { Kingdom }\end{array}$ & Wind energy & Renewable sources or energy \\
\hline
\end{tabular}

The table is a point of reference for the analysis, which aims to fully illustrate the qualitative variables, i.e., the factors determining the selection of RES promotion tools by the centers of the Enterprise Europe Network. The EEN centers choose the topics of their meetings independently, 
according to the needs of their clients. As demonstrated in Table 1, topics related to RES are very popular among entrepreneurs, which prompts the event organization. The proximity of international trade fairs also has a huge impact on the organization of BM, as they are usually organized as accompanying events. Every year, EEN centers report on their activities, e.g., on the number of BM organized, their participants (clients), the number of meetings held by these clients and the number of partnership agreements (PA) signed as a result of the BM. The above are the foundation of the MB effectiveness assessment, and a potential follow-up in the future.

The maps visualizing the results were created with the ESRI software ArcGIS 10, the graphs-in Microsoft Excel program. Maps present simple cartograms of all analyzed meetings (all brokerage events and company missions). Meetings of the same type and taken place in the same country, were summed up and devided into 5 classes. The classes were calculated with the quantile method, i.e., each class included an equal number of objects in one class (meetings), and no class was empty. This visualization method was used due to the large linear dispersion of the data. Moreover, the transnational meetings of each type were presented as a percentage of all meetings and divided into 3 or 4 classes, manualy, with the use of the expert method, in the way for the best presentation of the data. Both figures show the Euroasian continent but on the Figures 1 and 2, Chile is in the large scale map as the only country outside Euroasia where meetings took place. The cartographic method aims ony to visualize data, this is not a statistical or analytical method. However, it is proved that visualization, except the obvious benefits also helps the interpretation of data. This is also the case here.

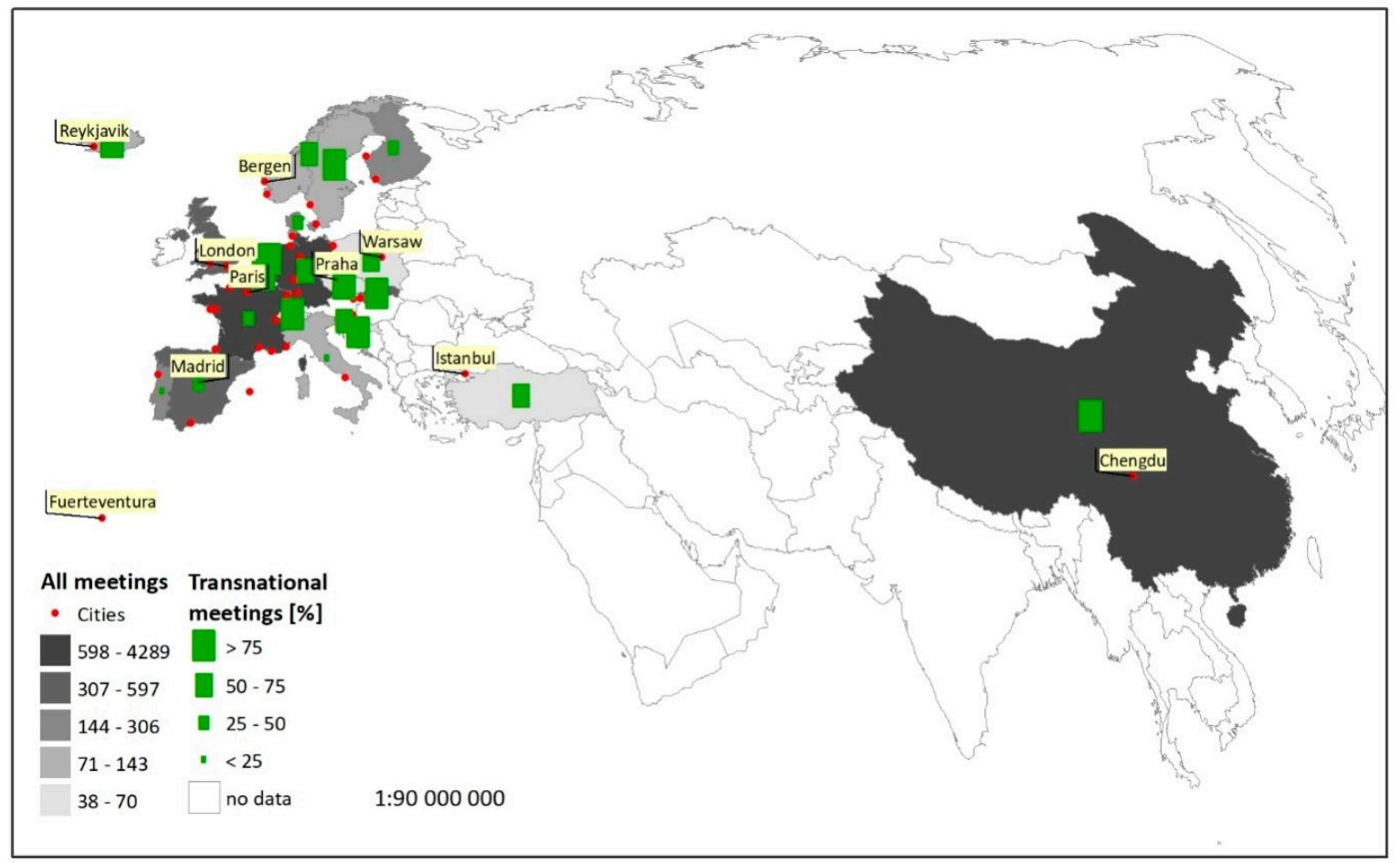

Figure 1. All brokerage event meetings, in a global perspective, including transnational. 


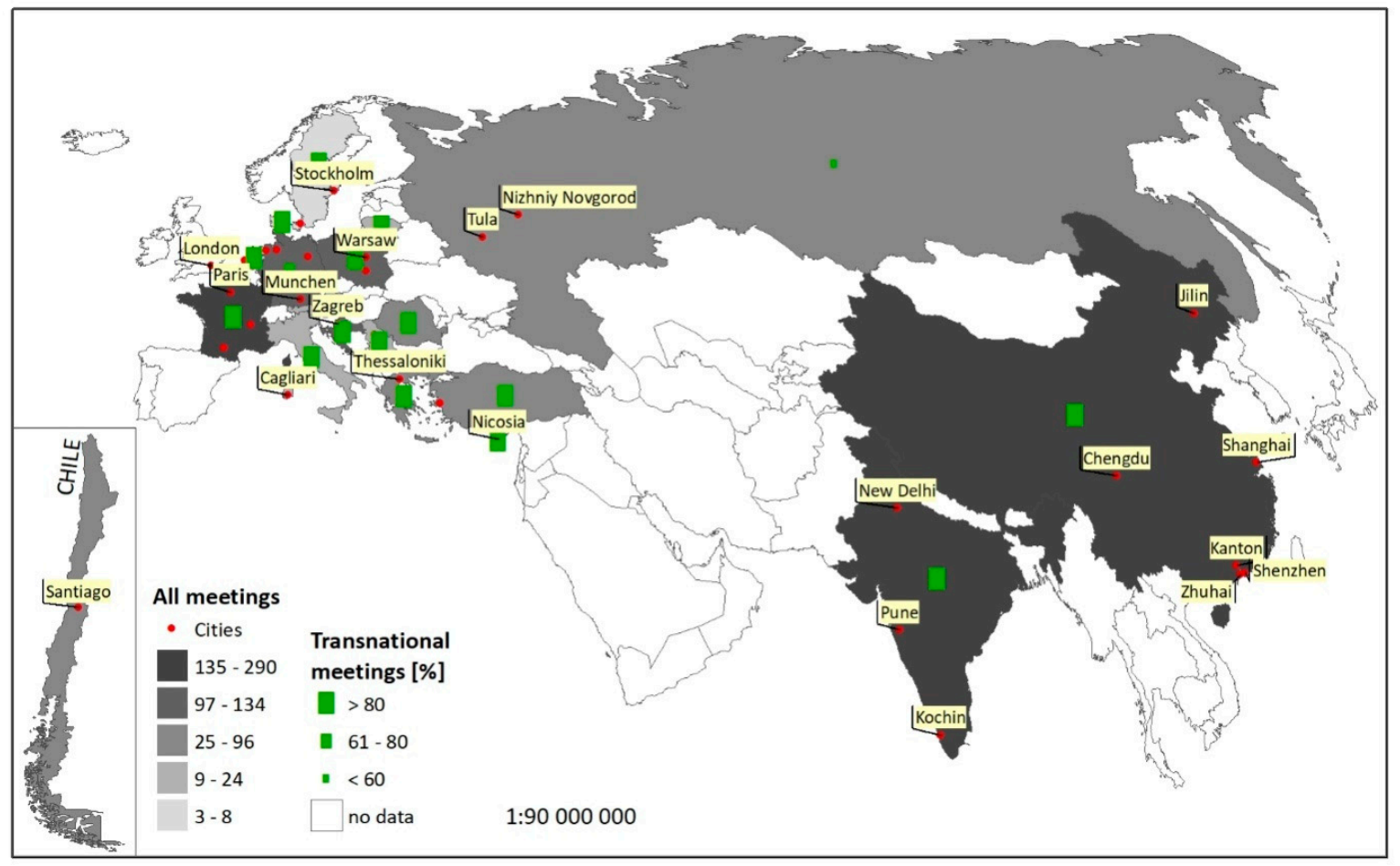

Figure 2. All company mission meetings, in a global perspective, including transnational.

\section{Results and Discussion}

In the course of the research it was found that in the analyzed period there were 12,769 BE meetings and 1922 CM meetings, taking place in 47 and 36 cities around the world, respectively. In some cases, these meetings were held at the same time in two or several cities. For example, the Smart cities trade delegation took place at the India-UK Tech Summit, in New Delhi, Pune and Kochi (India), or the French SMEs Delegation to China took place in Shanghai, Chengdu, Shenzhen, Canton and Zhuhai. Apart from European countries, these meetings took place in Chile, China and India, as illustrated in Figures 1 and 2.

Most of the meetings, both BE and CM, were international ( $63 \%$ and $89 \%$, respectively). Thematic maps with bar diagrams in Figures 3 and 4 also present the percentage of transnational meetings (in the total number of meetings), per every country where they took place. These data are highly dispersed (greater for $\mathrm{BE}$ ) and range from $12 \%$ to $100 \%$ for $\mathrm{BE}$ and $50 \%$ to $100 \%$ for CM. Most BE meetings took place in France (4289). They were associated with energy efficiency; waste to energy; low, zero and plus energy rating and environmental engineering (wind, marine and alternative energy). Also, many took place in Germany (2814) and Belgium (1437). The fewest meetings were held in the Czech Republic (38), Croatia (44), Switzerland (45), Poland (70) and Turkey (70). CM meetings took place mostly in the United Kingdom (439) and France (290). They were associated with energy conservation and wind energy in the UK, as well as with PV/thermal energy, energy for transport, pollution and recycling, oil and gas exploration and production in France.

There are four qualifications: (1) insufficient interest, no further contact is planned; (2) very informative, but no cooperation is planned; (3) cooperation is possible; and (4) cooperation has already been agreed. Upon analyzing the charts, it can be observed that the largest percentage of BE meetings concluded with the lack of further contact in Switzerland (27\%) and the lack of further cooperation in Croatia (23\%). However, countries such as Switzerland, Croatia, Sweden, Slovenia and Poland considered further cooperation possible in over $30 \%$ of cases. Finland was the only country that agreed to cooperate on a larger scale (11\%). CM meetings were characterized by a significantly higher percentage of no further cooperation, as well as of possible cooperation, or agreed cooperation. 
For example, in the UK, "Insufficient interest" or "No further contact planned" were indicated in 72\% of cases, while in Chile-30\%. A high percentage of "No cooperation planned" responses was also noted for Denmark-67\%, Sweden-50\%, Chile-42\%, Romania-41\%, Cyprus-38\%, Poland-29\%, Greece-29\%, UK-28\%, and "Further cooperation is possible" was indicated by Denmark in 33\%, Italy- $42 \%$, Serbia- $54 \%$, Croatia- $56 \%$ and Romania- $58 \%$. In Serbia, $25 \%$ of meetings ended with a consent for further cooperation and in Sweden, as much as 50\%. Please note that the participants of $\mathrm{CM}$ and $\mathrm{BE}$ were both representatives of the public administration, as well as business, especially the micro, small and medium-sized sector. The percentage of answers regarding possible cooperation and consent for further cooperation confirms the active search for new partners in enterprises operating in the RES sector, as well as the access to knowledge and necessary technologies.

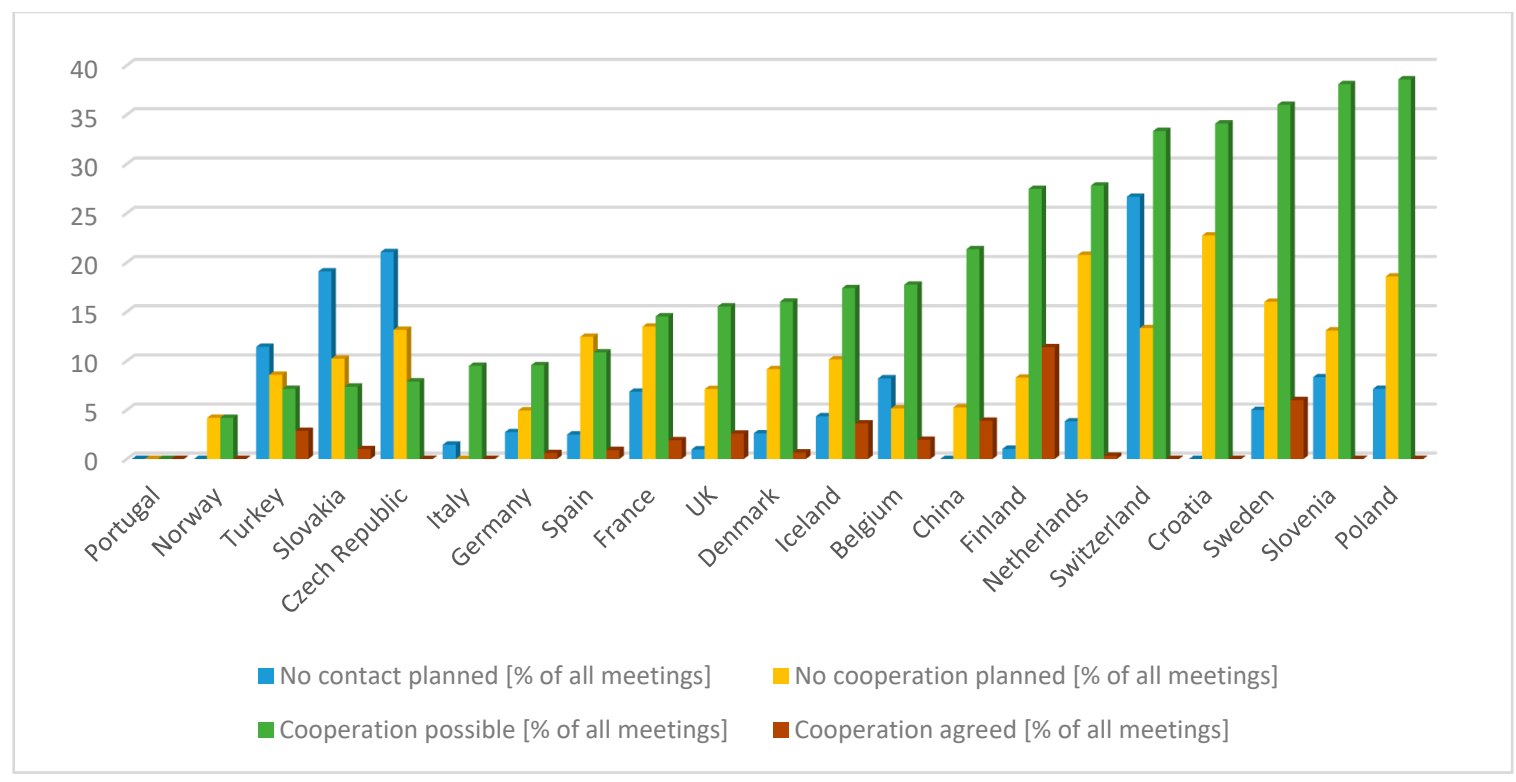

Figure 3. Further cooperation possibilities following brokerage events, in all countries.

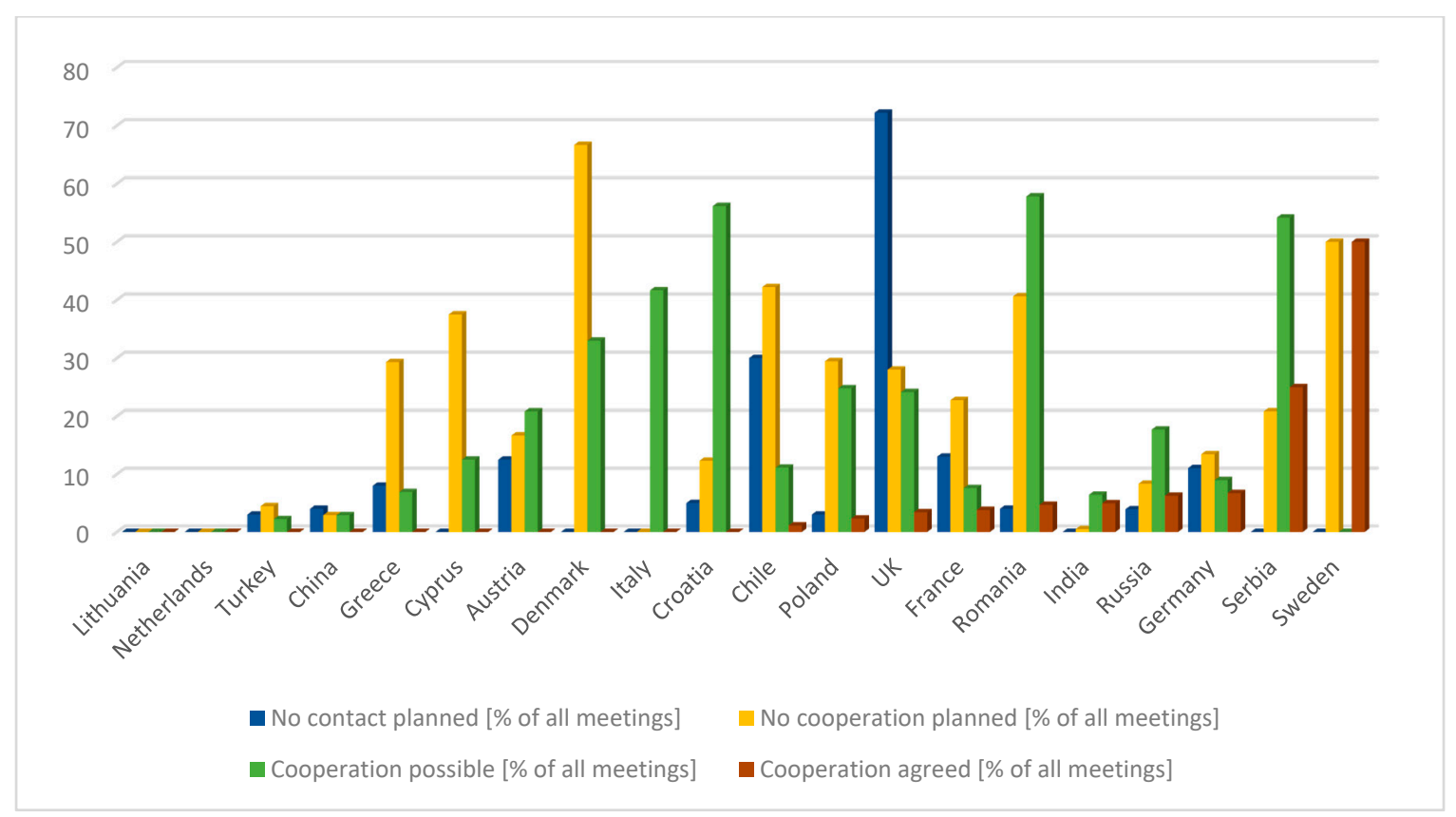

Figure 4. Further cooperation possibilities following company missions, in all countries. 
According to Eurostat [36], in 2018 Denmark achieved a 36.1\% RES share of its national energy mix, exceeding its national target for 2020 by 6.1 percentage points. Lithuania was in a similar situation, reaching $24.4 \%$ against the national target of $23 \%$. Austria achieved a $33.4 \%$ RES share in its national energy mix in 2018 against a 34\% target for 2020. In 2018, Luxembourg came very close to its target set at $11 \%$, increasing the share of RES from $6.4 \%$ to $9.1 \%$ in the years $2017-2018$. However, the country's authorities have already started negotiations with e.g., Lithuania, from which they want to buy back the missing "virtual" volume of green energy in order to fulfil their commitment for 2020. Spain was 2.6 percentage points short of its $20 \%$ target in 2018, while in Ireland the situation was much worse, with $11.1 \%$ of the national target of $16 \%$ achieved.

Upon analyzing the range of technologies presented during BE and CM, it has been deemed necessary to demonstrate the associations and cooperation between the host countries. At the initiative of Lithuania, and with support of Poland, Latvia, Austria, Estonia, Greece, Luxembourg and Spain, the countries have appealed to the European Commission to take action to achieve the sustainable development objectives set out in the so-called European Green Deal [37]. Renewable energy sources, especially wind- and sun-based, will play a key role in achieving EU's climate neutrality. It has been pointed out that one of the most important tasks will be to build the main elements of this system (including the supply system) in Europe. This will not only achieve the climate goals, but will also bring economic benefits to the Old Continent. The signatory states postulate that wind and sun, as well as green energy storage technologies should become the main investment elements of European green governance.

Increased investment in sustainable energy sources is also the result of China's active participation in international life. As a signatory of the 2016 Paris Agreement, China has committed to increase the share of sustainable energy in the overall consumption model to $20 \%$ by 2030 [38]. Joining the agreement has forced China mainly to re-evaluate the current model of energy economy and introduce significant changes. Apart from investments, China is also looking for foreign markets for "green" technologies. Europe's potential partner may be Central Asia, which lacks sufficient infrastructure, despite a huge potential related to its geographical conditions. The Chinese have become leaders in the world's solar panel production as early as the last decade. What is more, the 2016 export of RES technologies reached USD 83 billion, which exceeds $24 \%$ of the global market share [39].

\section{Conclusions}

Renewable energy is one of the key interdisciplinary issues included in EU policies. The European Union and its Member States have become a global leader in the development and implementation of RES. As a result, RES and their support under EU policies are strongly anchored in development strategies, goals and priorities, as well as in binding regulations.

RES are a key element of EU's sustainable development. Their goal is to obtain energy from natural, repetitive processes and thus limit the exploitation of conventional sources, i.e., using non-renewable resources. In addition, due to their positive impact on the natural environment, RES are one of EU's priorities in terms of energy policy. Thus, having a wide range of instruments to support the promotion of RES, EU popularizes these technologies, also through technology transfer networks.

The article demonstrates the importance of transnational technology transfer networks in the promotion of RES during company mission and brokerage events. It has been demonstrated that the discussed events, organized at the initiative of the EEN are becoming a platform for the exchange of experiences and contacts, as well as signing contracts for RES. Different levels and types of institutional interaction can affect efficiency in different ways, with the sharing of procedural information and coordination mechanisms being considered most fruitful for increasing efficiency.

Electricity is an important part of the economic development of each country, with a steadily growing demand. In recent years there has been a sharp increase in the share of renewable energy in total energy production [40] and in the light of the numerous regulations, directives and laws created in Europe, its importance will further increase in the near future. At the same time, the share of nuclear 
energy and coal is decreasing and that of oil and gas from conventional and unconventional deposits is increasing. In this context, the existing trend of increasing the importance of electricity production from renewable sources seems irreversible. However, this does not mean that the introduction of large anthropogenic objects into the environment is not opposed. This is why an international discussion seems so important, to introduce numerous mechanisms and instruments leading to promoting RES by emphasizing their importance within the technology transfer network, as well as to build international networks, such as the Enterprise Europe Network.

Apart from the environmental aspects, energy (including renewable energy) covers both the political and economic aspects of international business relations as an important aspect of sustainable development. According to Sustainable Development Goals, energy is a subject of the 7th goal, but also a part of the 17th goal. The concept of sustainable development is laudable, as it is based on counteracting the broadly understood degradation of the Earth's natural and cultural environment and on harmonious business activity. Thus, it has found many supporters virtually all over the world, and its implementation is financially supported by numerous private institutions and international organizations. The Enterprise Europe Network is an example of an institutional network promoting technology transfer for sustainable development of renewable energy.

Sustainable development is a multidimensional idea which, apart from the natural, economic and social aspects of man's environmental behavior, also means the institutional, spatial, moral and spiritual aspects of life related to its quality, although not necessarily considered as material goods. This concept is universally desirable because its main premise is progress, and this gives an opportunity for proper, sensible spatial planning and management [41]. This seems all the more important as the exploitation of natural resources (including fossil fuels) often remains uncontrolled. Many locations experience a significant environmental imbalance caused, on the one hand, by increased consumption and, on the other hand, by a lack of compensation for the environmental and social losses. Probably not many researchers already doubt whether Naveh was correct [42] in saying that the sustainability revolution in all spheres of life should be a key element of further research. With no understanding of the need for a systemic and multidimensional approach to human-environmental relations, the idea of sustainable development will be doomed to failure. This approach requires the implementation of numerous political, legal and economic solutions in the functioning of many local, national or even international institutions [43-45].

The presented results are the foundation for future theoretical and practical studies. One of the important aspects to be examined is the intensity of cooperation launched during CM and BE. It is related to the results of partnership agreements and the importance of increasing the knowledge flow and creating opportunities for partners to acquire foreign technologies.

To summarize the conclusions:

1. Institutions operating within transnational technology transfer networks have an important role to play in RES technology transfer.

2. BEs and CMs have become a platform for the exchange of experience and contacts, as well as for signing transfer and diffusion contracts on RES innovations. The nature of BE and CM and the possibility to organize meetings in a virtual company is of particular importance during the COVID-19 pandemic period.

3. The types of institutional interactions can significantly influence the efficiency and effectiveness of RES technology transfer.

4. When creating the next EU energy policy program framework, introduction of numerous mechanisms and instruments leading to the promotion of RES should be considered, with emphasis on their importance in technology transfer networks. Building international networks should also be taken into view, following the example of the Enterprise Europe Network.

5. Building transnational partnerships aimed at the exchange of experience and knowledge on the development and improvement of RES efficiency has become necessary, based on geographical and regional conditions. 
Author Contributions: Conceptualization, Z.G.-S., A.S.-S. and M.L.; methodology, J.S., M.N., M.L.; validation, L.O.S., E.V., M.L.; formal analysis, Z.G.-S., M.L.; resources, J.S., M.N.; data curation, L.O.S., E.V.; writing-original draft preparation, M.L., Z.G.-S., A.S.-Z.; writing-review and editing, J.S., M.N.; visualization, M.L., Z.G.-S.; supervision, A.S.-S., J.S.; project administration, Z.G.-S., M.L., A.S.-S. All authors have read and agreed to the published version of the manuscript.

Funding: Publication financed by the subsidy granted to the Cracow University of Economics.

Conflicts of Interest: The authors declare no conflicts of interest.

\section{References}

1. Walrave, B.; Talmar, M.; Podoynitsyna, K.S.; Romme, G.L.; Verbong, G.P.J. A multi-level perspective on innovation ecosystems for path-breaking Innovation. Technol. Forecast. Soc. Chang. 2018, 136, $103-113$. [CrossRef]

2. Weber, K.M.; Rohracher, H. Legitimizing research, technology and innovation policies for transformative change: Combining insights from innovation systems and multi-level perspective in a comprehensive 'failures' framework. Res. Policy 2012, 41, 1037-1047. [CrossRef]

3. Flanagan, K.; Uyarra, E. Four dangers in innovation policy studies-and how to avoid tchem. Ind. Innov. 2016, 23, 177-188. [CrossRef]

4. Reichardt, K.; Rogge, K.S. How the policy mix impacts innovation: Findings from company case studies on offshore wind in Germany. Environ. Innov. Soc. Trans. 2016, 18, 62-81. [CrossRef]

5. Rogge, K.S.; Reichardt, K. Policy mixes for sustainability transitions: An extended concept and framework for analysis. Res. Policy 2016, 45, 1620-1635. [CrossRef]

6. Meng, X.; Yilmaz, S. Renewable energy cooperation in Northeast Asia: Incentives, mechanisms and challenges. Energy Strategy Rev. 2020, 29, 100468.

7. Kydd, H.A. Trust and Mistrust in International Relations; Princeton University Press: Princeton, NJ, USA, 2005.

8. Koremenos, B.; Lipson, C.; Duncan, S. The rational design of international institutions. Int. Organ. 2001, 55, 761-800. [CrossRef]

9. Shirley, M. Institutions and Development. In Handbook of New Institutional Economics; Ménard, M.S., Ed.; Springer: Dordrecht, The Netherlands, 2005.

10. Sanderink, L.; Nasiritousi, N. How institutional interactions can strengthen effectiveness: The case of multi-stakeholder partnerships for renewable energy. Energy Policy 2020, 141, 111447. [CrossRef]

11. Akkurt, G.G.; Aste, N.; Borderon, J.; Buda, A.; Calzolari, M.; Chung, D.; Costanzo, V.; Del Pero, C.; Evola, G.; Huerto-Cardenas, H.E.; et al. Dynamic thermal and hygrometric simulation of historical buildings: Critical factors and possible solutions. Renew. Sustain. Energy Rev. 2020, 118, 109509. [CrossRef]

12. Gródek-Szostak, Z.; Szelagg-Sikora, A.; Sikora, J.; Korenko, M. Prerequisites for the cooperation between enterprises and business supportinstitutions for technological development. In Proceedings of the 16th Conference, Tomaszowice, Poland, 19-20 June 2017; Volume 16, pp. 427-439.

13. Niemiec, M.; Komorowska, M.; Szelag-Sikora, A.; Sikora, J.; Kuboń, M.; Gródek-Szostak, Z.; Kapusta-Duch, J. Risk Assessment for Social Practices in Small Vegetable farms in Poland as a Tool for the Optimization of Quality Management Systems. Sustainability 2019, 11, 3913. [CrossRef]

14. Szeląg-Sikora, A.; Sikora, J.; Niemiec, M.; Gródek-Szostak, Z.; Kapusta-Duch, J.; Kuboń, M.; Komorowska, M.; Karcz, J. Impact of Integrated and Conventional Plant Production on Selected Soil Parameters in Carrot Production. Sustainability 2019, 11, 5612. [CrossRef]

15. Kapusta-Duch, J.; Szeląg-Sikora, A.; Sikora, J.; Niemiec, M.; Gródek-Szostak, Z.; Kuboń, M.; Leszczyńska, T.; Borczak, B. Health-Promoting Properties of Fresh and Processed Purple Cauliflower. Sustainability 2019, 11, 4008. [CrossRef]

16. Gródek-Szostak, Z.; Malik, G.; Kajrunajtys, D.; Szelagg-Sikora, A.; Sikora, J.; Kuboń, M.; Niemiec, M.; Kapusta-Duch, J. Modeling the Dependency between Extreme Prices of Selected Agricultural Products on the Derivatives Market Using the Linkage Function. Sustainability 2019, 11, 4144. [CrossRef]

17. Niemiec, M.; Chowaniak, M.; Sikora, J.; Szelag-Sikora, A.; Gródek-Szostak, Z.; Komorowska, M. Selected Properties of Soils for Long-Term Use in Organic Farming. Sustainability 2020, 12, 2509. [CrossRef] 
18. Sikora, J.; Niemiec, M.; Tabak, M.; Gródek-Szostak, Z.; Szelagg-Sikora, A.; Kuboń, M.; Komorowska, M. Assessment of the Efficiency of Nitrogen Slow-Release Fertilizers in Integrated Production of Carrot Depending on Fertilization Strategy. Sustainability 2020, 12, 1982. [CrossRef]

19. COM/2015/080. Communication from the Commission to the European Parliament, the Council, the European Economic and Social Committee, the Committee of the Regions and the European Investment Bank A Framework Strategy for a Resilient Energy Union with a Forward-Looking Climate Change Policy; COM/2015/080: Brussels, Belgium, 2015.

20. Fiorini, A.; Georgakaki, A.; Pasimeni, F.; Tzimas, E. Monitoring REI in Low-Carbon Energy Technologies; Publications Office of the European Union: Luxembourg, 2017.

21. Hooglan, O.; Van der Lijn, N.; Rademaekers, K.; Gentili, P.; Colozza, P.; Morichi, C. Assessment of Photovoltaics (PV) Task F Strategies to Rebuild the European PV Sector; Trinomics: Rotterdam, The Netherlands, 2017.

22. Taherdangkoo, R.; Tatomir, A.; Anighoro, T.; Sauter, M. Modeling fate and transport of hydraulic fracturing fluid in the presence of abandoned wells. J. Contam. Hydrol. 2019, 221, 58-68. [CrossRef]

23. Tatomir, A.; McDermott, C.; Bensabat, J.; Class, H.; Edlmann, K.; Taherdangkoo, R.; Sauter, M. Conceptual model development using a generic Features, Events, and Processes (FEP) database for assessing the potential impact of hydraulic fracturing on groundwater aquifers. Adv. Geosci. 2018, 45, 185-192. [CrossRef]

24. Karakosta, C. A holistic approach for addressing the issue of effective technology transfer in the frame of climate change. Energies 2016, 9, 503. [CrossRef]

25. Pradesha, A.; Robinson, S.; Mondal, M.; Alam, H.; Valmonte-Santos, R.; Rosegrant, M.W. Green Growth Strategy: The Economywide Impact of Promoting Renewable Power Generation in the Philippines; The International Food Policy Research Institute: Washington, DC, USA, 2019; Volume 1802.

26. Withanaarachchi, A.S. The role of technology transfer and cooperation for the development of wind power sector in Sri Lanka: A case based approach. Int. J. Eng. Sci. 2016, 5, 96-106.

27. Atalay, Y.; Biermann, F.; Kalfagianni, A. Adoption of renewable energy technologies in oil-rich countries: Explaining policy variation in the Gulf Cooperation Council states. Renew. Energy 2016, 85, 206-214. [CrossRef]

28. Buchholz, W.; Dippl, L.; Eichenseer, M. Subsidizing renewables as part of taking leadership in international climate policy: The German case. Energy Policy 2019, 129, 765-773. [CrossRef]

29. Liu, H.; Liang, X. Strategy for promoting low-carbon technology transfer to developing countries: The case of CCS. In Energy Policy; Elsevier: Amsterdam, The Netherlands, 2011; Volume 39, pp. 3106-3116.

30. Seres, S.; Haites, E.; Murphy, K. Analysis of technology transfer in CDM projects: An update. Energy Policy 2009, 37, 4919-4926. [CrossRef]

31. Sipilä, K.; Rämä, M.; Pursiheimo, E.; Sokka, L.; Löf, A.; Niemi, R.; Konttinen, J.; Rodriguez, M.; Ruggiero, S.; Maunuksela, J.; et al. Distributed energy systems-DESY. VTT Technol. 2015, 224, 186.

32. Moreno, B.; Lopez, A.J. The Effect of Renewable Energy on Employment. The Case of Asturias (Spain). Renew. Sustain. Energy Rev. 2008, 12, 732-751. [CrossRef]

33. Ferraro, G.; Iovanella, A. Technology transfer in innovation networks: An empirical study of the Enterprise Europe Network. Int. J. Eng. Bus. Manag. 2017, 9. [CrossRef]

34. Gródek-Szostak, Z.; Luc, M.; Szelagg-Sikora, A.; Niemiec, M.; Kajrunajtys, D. Economic Missions and Brokerage Events as an Instrument for Support of International Technological Cooperation between Companies of the Agricultural and Food Sector. In Infrastructure and Environment; Springer: Cham, Switzerland, 2019; pp. 303-308.

35. Gródek-Szostak, Z.; Luc, M. Company mission events i brokeage events jako narzędzia wsparcia międzynarodowej współpracy technologicznej. In Zarządzanie Restrukturyzacją: Innowacyjność $i$ Konkurencyjność w Obliczu Zmian; Towarzystwo Naukowe Organizacji i Kierownictwa; Dom Organizatora: Toruń, Poland, 2019; pp. 231-239.

36. EUROSTAT. Available online: https://www.gramwzielone.pl/trendy/102657/szesc-panstw-unii-europejskiejchce-celu-100-proc-energii-z-ozedostęp (accessed on 17 June 2020).

37. CIRE, Polska i Kilka Państw UE chce Wzmocnienia Współpracy na Rzecz OZE. Available online: https://www.cire.pl/item,197755,1,0,0,0,0,0,polska-i-kilka-panstw-ue-chce-wzmocnienia-wspolpracy-narzecz-oze.html (accessed on 20 June 2020).

38. Paris Agreement-China's Pledges and Targets. Available online: https://climateactiontracker.org/countries/ china/pledges-and-targets/ (accessed on 17 June 2020). 
39. Cao, X.; Rajarshi, A.; Tong, J. Technology Evolution of China's Export of Renewable Energy Products. Int. J. Environ. Res. Public Health 2018. Available online: https://www.ncbi.nlm.nih.gov/pmc/articles/PMC6121901/ (accessed on 17 June 2020).

40. OECD/IEA 2014. Electricity Production from Renewable Sources, Excluding Hydroelectric (kWh). Available online: https://data.worldbank.org/indicator/EG.ELC.RNWX.KH?end=2015\&start=1990\&view= chart) (accessed on 5 June 2020).

41. Luc, M. Placing the idea of sustainable landscape in ecophilosophy. Probl. Sustain. Dev. 2014, 9, 81-88.

42. Naveh, Z. Multifunctional, self-organizing biosphere landscapes and the future of our total human ecosystem. World Futures 2004, 60, 469-503. [CrossRef]

43. Luc, M. Użytkowanie Ziemi w Badaniu Krajobrazu Zrównoważonego; IGiGP UJ: Kraków, Poland, 2018.

44. Sikora, J.; Niemiec, M.; Szelag-Sikora, A.; Gródek-Szostak, Z.; Kuboń, M.; Komorowska, M. The Impact of a Controlled-Release Fertilizer on Greenhouse Gas Emissions and the Efficiency of the Production of Chinese Cabbage. Energies 2020, 13, 2063. [CrossRef]

45. Velinov, E.; Petrenko, Y.; Vechkinzova, E.; Denisov, I.; Ochoa Siguencia, L.; Gródek-Szostak, Z. “Leaky Bucket” of Kazakhstan's Power Grid: Losses and Inefficient Distribution of Electric Power. Energies 2020, 13, 2947. [CrossRef]

(C) 2020 by the authors. Licensee MDPI, Basel, Switzerland. This article is an open access article distributed under the terms and conditions of the Creative Commons Attribution (CC BY) license (http://creativecommons.org/licenses/by/4.0/). 